\title{
MARTIN, CRAIG. MASKING HEGEMONY: A GENEALOGY OF LIBERALISM, RELIGION AND THE PRIVATE SPHERE. LONDON: EQUINOX, 2010.
}

Renan Santos ${ }^{1}$

O debate a respeito do papel das religiões no espaço público tem capitaneado a atenção de muitos cientistas sociais nas últimas décadas. No caso do Brasil, a progressiva inserção de grupos religiosos defendendo bandeiras confessionais na arena política (como nos casos de projetos de lei para descriminalizar o aborto ou conceder união civil para casais do mesmo sexo) tem desafiado as noçóes e os significados conferidos à laicidade e à secularização. Se o processo histórico de construção da modernidade requer a dissociação entre Estado (domínio do público) e religiōes (relegadas ao âmbito privado), como explicar os constantes atravessamentos entre essas supostas "esferas" separadas? Uma possibilidade de enfrentamento da questão é a proposta por Craig Martin em seu livro Masking Hegemony, lançado em 2008.

Professor assistente no St. Thomas College e editor do Bulletin for the Study of Religion, em Masking Hegemony, o autor propõe-se a analisar a maneira como o discurso da separação entre religião e Estado (invocado na arena política tanto por setores conservadores quanto liberais) foi construído historicamente, iniciando pelo modo como tal retórica se apresenta hoje em dia, nos Estados Unidos, evidenciada pela acusação de que alguém está “[...] usando a religião". Afirmar que alguém "usa a religião por motivos políticos" pressupõe a separação de esferas e sugere que religião é algo necessariamente apolítico, uma questão privada insubmetível à razão pública.

Martin deixa muito claro seu posicionamento: considera falso afirmar que religiōes são apolíticas (ou que aqueles que as usam na política fazem

\footnotetext{
${ }^{1}$ Mestrando em Antropologia Social (PPGAS/UFRGS), pesquisador associado do Núcleo de Estudos da Religião (NER/UFRGS). E-mail: renan.santos.ufrgs@gmail.com
} 
um "mau uso" delas), visto que "a maioria das tradições que chamamos coloquialmente como "religiosas" habituam cidadãos em ideologias e desejos com conseqüências políticas, produzindo, portanto, atores políticos" (p. 2). Dessa maneira, a suposição de que "[...] religião é apolítica" acaba sendo usada para avançar interesses de duas maneiras distintas: (a) para dizer que ideologias de grupos religiosos são irrelevantes para as decisões políticas; (b) para criticar o envolvimento de tradiçōes religiosas na esfera política, sendo que as "boas" são as que não se envolvem, e as "más" as que o fazem.

No intuito de discutir esses mecanismos retóricos, o autor divide seu argumento em quatro partes ao longo do livro:

(1) Começa fazendo uma análise rigorosa da relação entre instituições privadas e públicas e os esquemas conceituais sofisticados por elas requeridos, bem como discorre sobre a ambiguidade do termo "religião" (capítulo 1). $\mathrm{O}$ autor destaca a importância da teoria construcionista, além dos vários estudos da genealogia da palavra religião nos anos 90; mas afirma que há mais a se fazer do que criticar a reificação, sendo seu interesse maior o de focar nas manobras retóricas possibilitadas pelas taxonomias múltiplas e cadeias de associação contraditórias num mesmo contexto.

(2) Debate o uso do termo "religião" no início da era moderna, no intuito de demonstrar o quanto diversas práticas e ideologias cristãs informaram e formataram os Estados europeus da época (capítulo 2). Martin demonstra o quanto o relacionamento entre religião e política ficou mascarado por um mecanismo retórico enraizado no próprio discurso que propõe a separação dessas duas esferas, para debater a seguir as razões pelas quais esse mito se tornou tão popular.

(3) Por meio de uma leitura atenta de diversos textos de John Locke a respeito de filosofia política, Martin propõe-se a traçar o caminho por meio do qual instituiçôes supostamente privadas exercem sua influência no Estado (capítulo 3). A tentativa é de demonstrar o quanto o liberalismo de Locke é incapaz de estabelecer limites às ideologias e aos desejos "privados" de servirem como justificativa para as legislaçôes estatais.

(4) Martin volta sua atenção para a maneira como os binários público/ privado e religião/Estado aparecem no interior dos discursos políticos liberais 
contemporâneos a favor da neutralidade estatal em relação a ideologias particulares (capítulos 4 e 5). O autor disseca a retórica liberal que se utiliza do mesmo aparato ineficaz da separação de esferas e privatização da religião para demonstrar o quanto essa neutralidade estatal não é exequível e o próprio discurso que a defende permite que essas ideologias particulares (em especial, das instituições religiosas hegemônicas) acabem circulando de maneira livre e não questionada. A intenção de Martin é demonstrar o quanto os liberais que adotam esses binários incorrem em armadilhas retóricas que tornam seus argumentos incoerentes e/ou não persuasivos.

Em especial nesses dois capítulos finais, Martin demonstra como uma das mais importantes manobras retóricas, a do deslocamento ${ }^{2}$, ocorre no interior dos discursos políticos liberais, que defendem a separação igreja e Estado deslocando o que é tido como religioso para o mundo do privado, do não político. Para Martin, "[...] contradiçõos e deslocamento retórico vão de mãos dadas, contribuindo para a manutenção das contradiçōes" (p. 31), sendo que quem se beneficia dessas contradiçôes são os grupos hegemônicos, que não têm interesse em solvê-las, pois elas mascaram sua hegemonia.

$\mathrm{O}$ autor encerra o livro com a proposição de um esquema conceitual que lidaria melhor com a análise da maneira como o poder circula em todas essas "esferas".

Concluo enfatizando o argumento central do livro: embora nos processos de formação das repúblicas modernas tenha ocorrido uma mudança nas relaçõos entre igreja e Estado, segundo Martin, chamá-la de "separação" é inadequado. Para o autor, o que de fato ocorreu foi uma mudança de articulação da circulação de poder entre uma coisa e outra e "[...] o aparato conceitual que opõe "religião" e "Estado" (ou "privado" e "público") obscurece essa relação [de circulação de poder entre instituições civis e instituiçõos estatais]" (p. 110). A falha na identificação dessas articulações mantém a ideologia hegemônica cristã circulando livre no mundo,

\footnotetext{
${ }^{2}$ Nas palavras de Martin (p. 29): “[...] o processo de deslocamento ideológico ou retórico, por meio do qual um termo costumeiramente usado para se referir a um objeto ou indivíduo é usado para se referir a outro, e desse modo as conotações positivas e negativas do termo são transferidas de um outro objeto ou indivíduo.”
} 
moldando e formatando os corpos e desejos dos atores sociais, que depois irão atuar na esfera pública orientados por essa ideologia. Sem a devida problematização, esses discursos ideológicos religiosos acabam sendo tomados como o parâmetro de normalidade no interior do qual os indivíduos são socializados - e é a partir dessas concepções de normalidade que os cidadãos tomarão suas decisões ao votarem ou ocuparem cargos públicos. Daí porque de o autor enfatizar a necessidade do uso de novas ferramentas analíticas pra melhor compreender essas circulações de poder. 